\title{
非外傷性頭蓋内疾患術後に発生した慢性硬膜下血腫
}

\author{
その病態的特徵 \\ 高橋 義男
}

\section{Pathogenetic Consideration on Chronic Subdural Hematoma after Intracranial Surgery for Nontraumatic Lesions}

\author{
Yoshio TAKAHASHI \\ Ohkawara Neurosurgical Hospital, Muroran, Hokkaido
}

\begin{abstract}
Most chronic subdural hematomas (CSH) are caused by trauma, but they sometimes occur nontraumatically or after surgery for nontraumatic intracranial disease. During the past 5 years, the author encountered 10 cases of postoperative CSH. They included five of 101 patients who had undergone extra-intracranial anastomosis $(5.0 \%)$, four of 177 who had received ventriculoperitoneal shunts $(2.3 \%)$, and one of 233 who had undergone aneurysmal repair $(0.4 \%)$. Computerized tomographic, operative, and pathological findings were the same as in traumatic CSH. Four cases were resolved by surgery and two by blocking of the shunt system; four patients recovered without therapy. CSH appears to develop under specific conditions, namely, cerebrospinal fluid or a mixture of blood and cerebrospinal fluid remain in the subdural space for a long interval. Cerebral compliance may play an important role in the aggravation of nontraumatic CSH.
\end{abstract}

Key words: chronic subdural hematoma, intracranial operation, cerebral compliance

\section{I はじめに}

慢性硬膜下血腫(以下 CSH) はま比外倁を契機として発 生するが，外傷の既往が明確でないもの 蓋内疾患の術後にも発生する4,7)ことが知られている。著 者は，過去 5 年間の非外傷性頭蓋内疾患の術後経過代おい $\tau, \mathrm{CT}$ 上10例に外傷性 $\mathrm{CSH}$ と同様の $\mathrm{CSH}$ 発生認め た。本稿でこの10例の原疾患, 手術方法, CSH 発生後 の治療経過などから，CSH の発生囘子おょび血腫増大因 子について检討し報告する。

\section{II 症 例}

\section{1. 非外傷性頭蓋内疾患の術後における CSH 発生率} 1979年 4 月以降 5 年間に大川原脸神経外科病院で経験し た外傷性疾患抢上び硬膜下水腫を除く非外傷性頭蓋内疾患 手術例は821例であり，その内訳は脳動脈溜根治術233例， 脳動静脈奇形根治術12例，脳内血腫除去術142例，頭蓋内 外血管吻合術 101 例，脳腫瘍摘出術 60 例，シャント術 177 例，持続脳室ドレナージ44例，その他52例であった。これ らのらち10例(1.2\%)において術後経過中にCSHの発生を 認めた，各手術後に拈汀る CSH 発生率は，頭蓋内外血管 吻合術がもっとも多く101例中 5 例 (5.0\%)，つでンャン

\footnotetext{
大川原脳神経外科病院

Address reprint requests to: Y. Takahashi, M.D., Department of Neurosurgery, Hokkaido Children's Hospital and Medical Center, 1-10-1 Zenibako, Otaru, Hokkaido 047-02.

受稿 1985年4月 5 日 受理 1987年 5 月20日
} 
卜術 177 例中 4 例 $(2.3 \%)$, 脳動眽溜根治術 233 例中 1 例 (0.4\%)て，他の術後㹩過にCSH の発生は諗めなかった。

2. 代表症例の呈示

以下に，典型的症例につい:略述持る。

<症例 $1>57$ 才, 男性 $(\mathrm{CSH}$ 手術例)

右不全片麻痺と運動性失語て入院した众中大脳動脈閉塞 の症例で，入院後症状は約 1 週間で改善したが，1力月徭 上り再び TIA 様に同様の症状を認めるようになったため， 発症後42日月に左頭蓋内外血管吻合術老行った。術前の plain CTでは左被設部に小さな低收收域(LDA)を誋めた が, contrast enhanced CT (CECT) では異常增强効果はみ られなかった（Fig.1A)。術後2日目のCTでは左前頭部 から頭頂部にかけて空気の集皘とLDAを認めたが(Fig. 1B)，術後10日日には空気集樍は㴗ぼ消失し，LDA b減 少した(Fig. 1C)。術後23日日では布前頭部はLDAとな り，減少便向にあった(Fig. 1D)。しかし，術後34月日の 言語訓練時に頭痛を訴え，CTにて左前頍および頙頂部に LDA と高吸收域 (HDA)が混在したCSHを認めた(Fig 1E)。翌日にはやや不榣状態となり，artifactのため明らか ではいわのの，CECTでCSH以容がやや堌強さ㧈比 較的 HDAとなり，脳室偏位も堌強してきた(Fig. 1F)。 $20 \%$ mannitol $1,000 \mathrm{ml} /$ 日の投与により経過を観察したが 血腫の縮小俚的礼ず，術後37日日に穿頭法に上る CSH 除土術が行初扎た，手術時，血腫は明らかな被膜妾有して おり，病理組織学的にも典型的な CSH の像を示した。 ま た，内容液暗赤色，流動性て FDP 䯩く，こ机も典型 的な CSH 像を呈していた。

<症例 $3>62$ 才, 男性 $(\mathrm{CSH}$ 自然治癒例)

右不全片麻痺と運動性失語て入院した左㠴大脳動脈閉塞 症例。入院後，麻瘦は改善したものの，運動性失語が血圧 低下時に要化寸る傾向孛認めたため，発症後31日月に左頭 蓋内外血管吻合術を行った。術前CTで戊右尾状核頭部の LDA と脳满の全体的な拡大を認め，CECTでは異常增強 効果は諗められなかった(Fig. 2A)，術後 CTでは，両側 前頭部に LDA を認めたが減少傾向にあった（Fig，2B），術 後33日目に在前頭部の LDAが比㥗的低吸収域 (RLDA) 之等吸収域(IDA) の混在与る吸收域(MDA) に变化 L $\mathrm{CSH}$ となり(Fig. 2C)，さらに73月日には雨側前頭部と半 IDAとなり，両側のCSHとなった(Fig. 2D)，その後俩 睡腔は増大せず，術後96日日には減少し，114日で消失し た〈Fig. 2E, F)。な抢，CSH 発生による症状の悪化はな く，导し万既存の应状做善傾向にあった。

〈症例 6>62才，男性 (CSH 手術例)

突然の頭痛により発症した高血生性小脑出血症例で，入 院時の CTで右小脳および第三・第四脳窒内に HDA を認
めた（Fig. 3A)，入院後，徐々代脳空出应大L(Fig. 3B)， 頭痛必持続したため，発症徭10日日に右側脳空一腹腔シャ ント術が行执机え。術㣪10日110 CTでは，脳室の縮小と

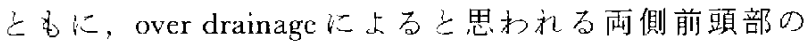

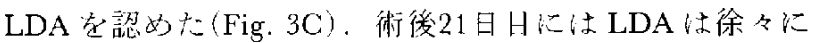
増大し，脳室は狭小化しはじめ，術後58日目には脎室はさ らに狭小化し，両側前頭部の LDAはIDAに変化し CSH となった(Fig. 3D,E).この頃らりンャント徭消失してい た頭痛を再び認め，20\% mannitol $1,000 \mathrm{~m} / /$ 日の投与.を行
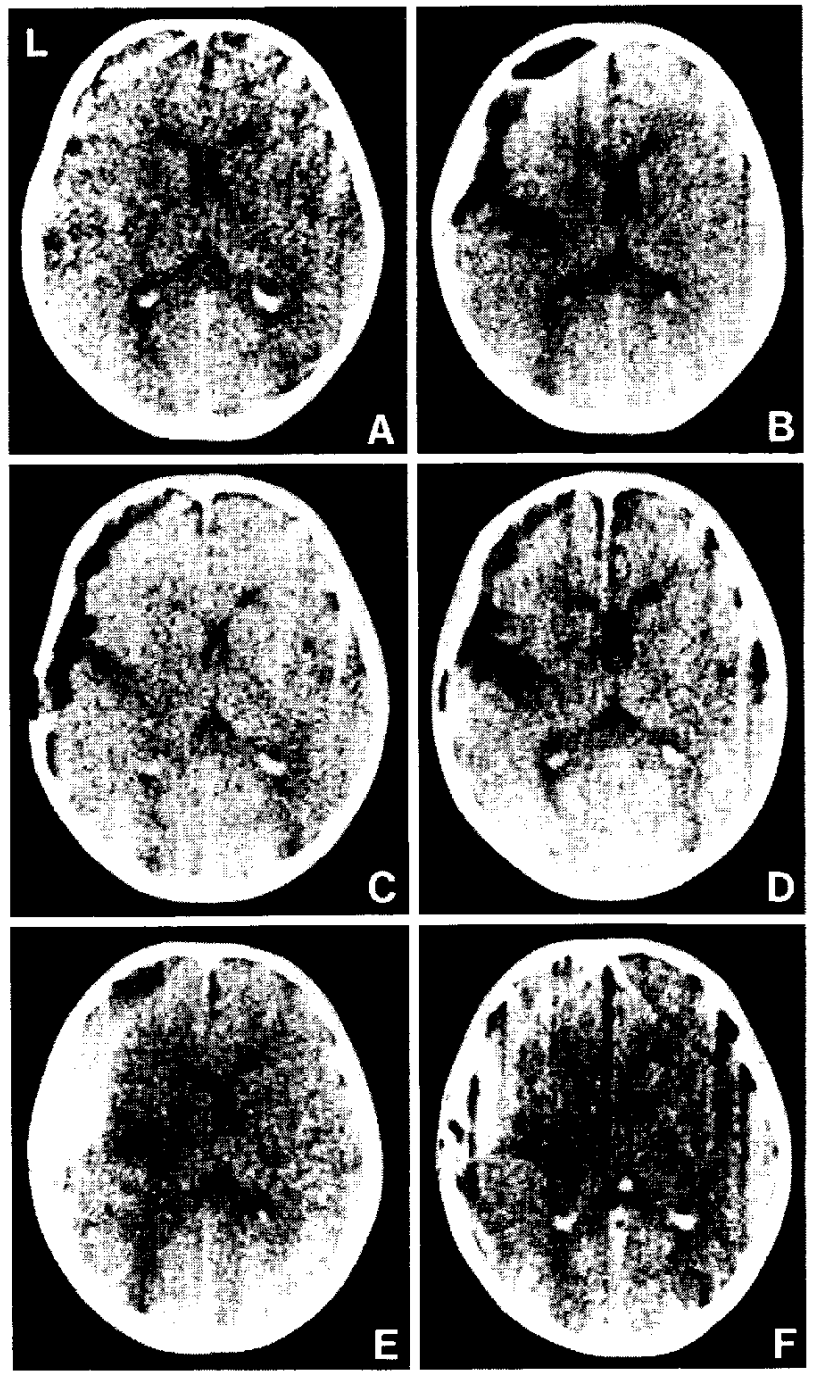

Fig. 1 Case 1. Ghronic subdural hematoma (CSH) after extraintracranial anastomosis. A: Preoperative computed tomography (CT) scan. B-D: A low-density area was seen in the left frontal region after surgery $(B$ : day $2, C$ : day 10, D: day 23). E: A mixed-density $\mathrm{CSH}$ was observed on day 34. F: Contrast-enhanced CT revealed an enhanced hematoma on day 35 . 

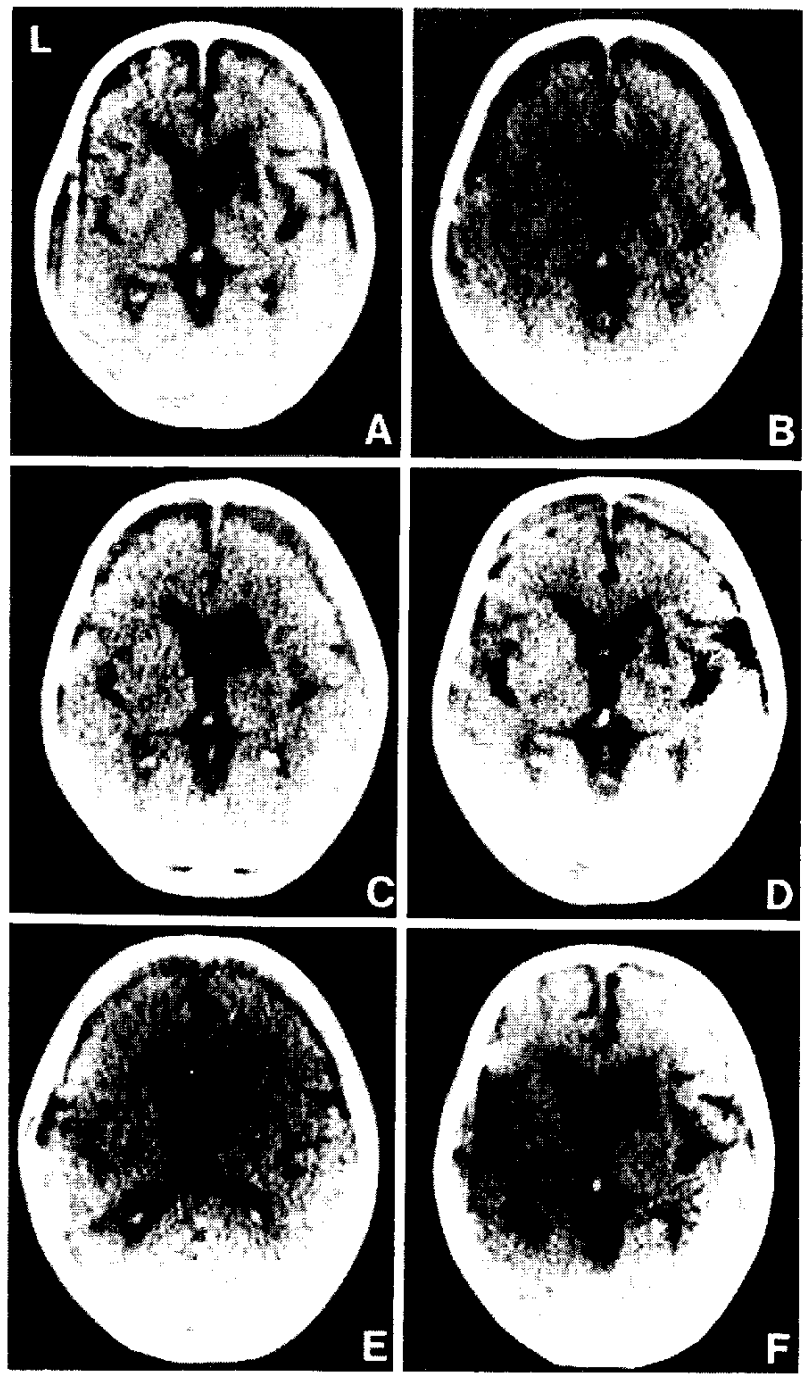

Fig. 2 Case 3. CSH after extra-intracranial anastomosis. A Preoperative CT scan. B: Postoperatively, a bifrontal low-density area was nored. C: A mixed-density CSH was observed on day 33 . D: The mixed-density area had changed to isodensity by day 73. E and F: The hcmatoma disappeared gradually without treatment ( $E$ day $96, \mathrm{~F}$ : day 114 )

った。しかし，血腫は減少せずMDAとなり（Fig. 3F 頭痛も持続したため，術㣦68日目に血腫除去術抢よびシャ ントメ゙ルブ(Heyer Schulte 社製 multipurpose valve) 孛 off にしてシャント谋断を行った，その後，血腫は䄪24日で消 头した。庄方，于術所見佉典型的 CSH上同様であった。

〈症例 $8>8$ 才，文兄くシャント遮断に上る CSH 治瘾 (列)

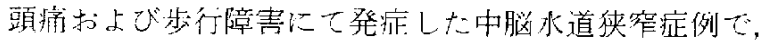
入院後 1 日目に右前頭部より脳至一腹腔シャント術が行わ
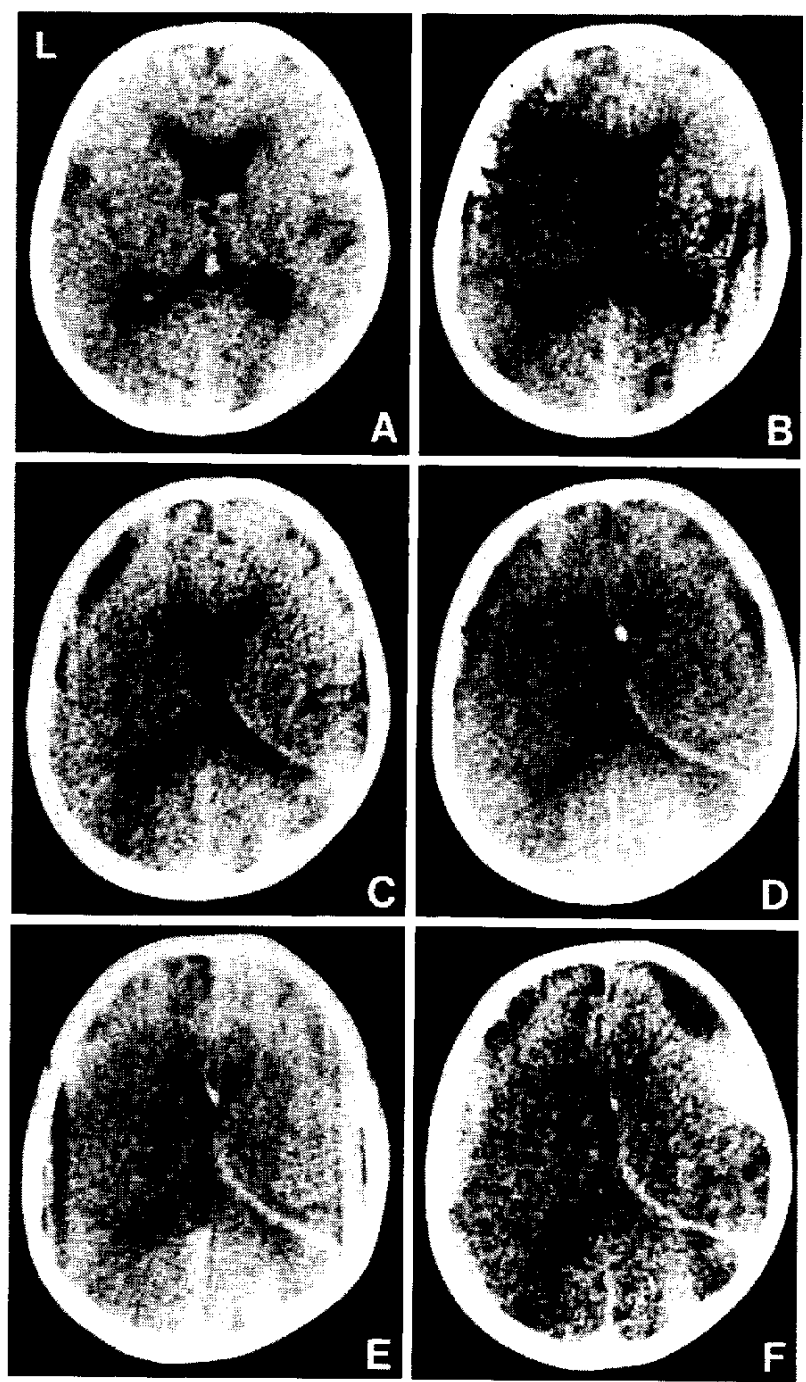

Fig. 3 Gase 6. CSH after ventriculoperitoneal shunting. A and B: Preoperative CT scans (A: intraventricular blceding, B: secondary hydrocephalus). G: A bifrontal low-density area was seen on postoperative day 10 . D: Day 21. The low-density area had gradually expanded. E: A bifrontal isodense CSH was observed on day 58. F: The isodense area did not decrease but had changed to mixed density by day 68 .

れた。術前のCTでは両側側脳室および第三脳空の著明な 掋大を認めたが，CEGTでは異常増強刘果は認めら扎な かった（Fig，4A)。シャント後，脳空涂々に小さくなり， 術徭15日日のCTでは脳室の樎小化以外に over drainage によると思われる両側前頭部の LDAを認めた(Fig. 4B)。 その後LDA は増大世ず経過を観察していたところ，術後 73 日目にLDA 结左側が IDA，右側が MDA 人上変化し， CSHとなった(Fig. 4C)，その後血腫量はやや増加したが 

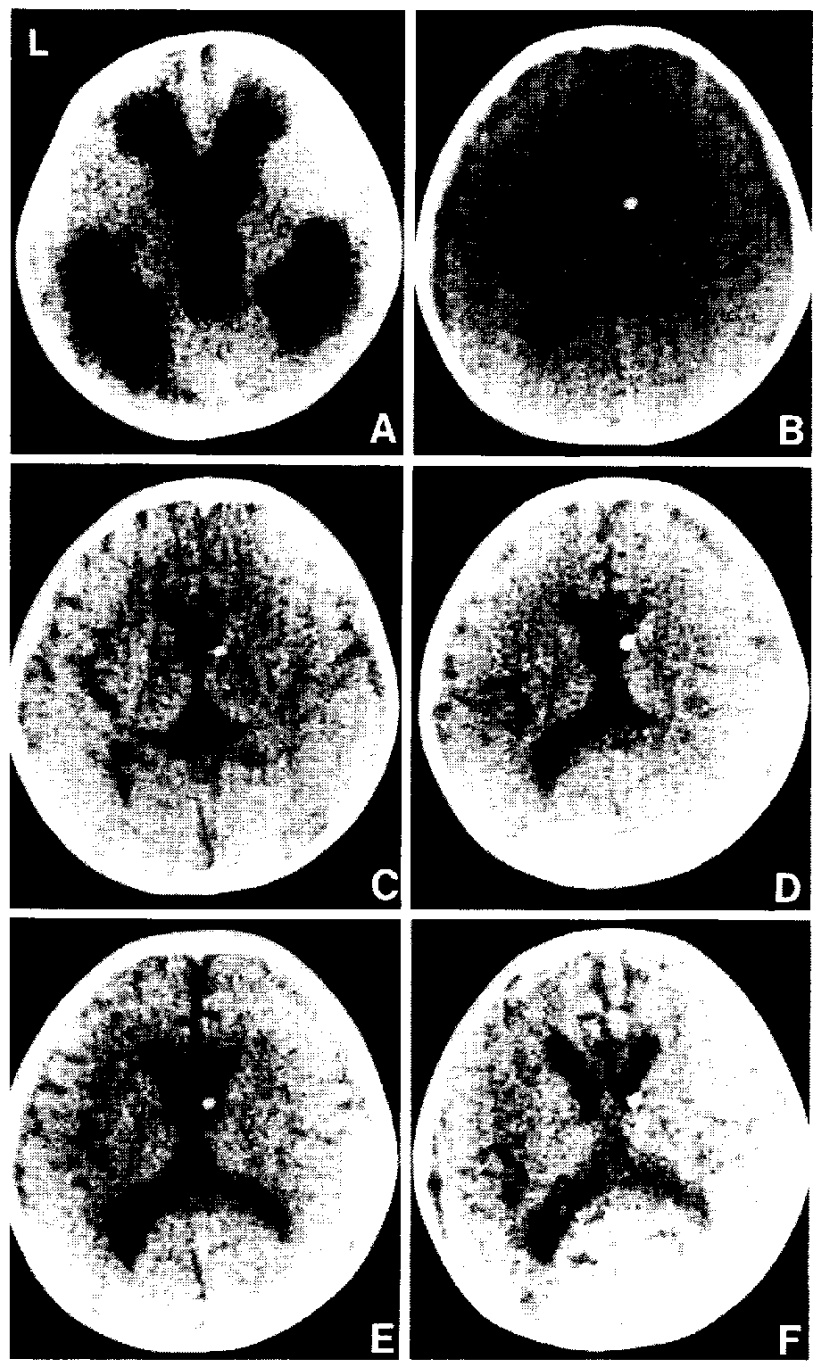

Fig. 4 Case 8. CSH after ventriculoperitoneal shunting. A: Preoperative CT scan. B: A bifrontal low-density area was seen on day 15 after surgery. C: A bifrontal isoand mixed-density CSH was demonstrated on day 73 . D-F: The hematoma disappeared gradually after blocking of the shunt (D: day $92, \mathrm{E}$; day $104, \mathrm{~F}$ : day 123 ).

症状はなく，術後84日日にシャントを遮断して経過観察を 行った。ンャント遮断後, 血腫は徐々飞減少しはじめ, 術 後92日月のCTては左 CSH は消失し，右 CSHはRLDA となった(Fig. 4D)。術後104山日には右 CSHは減少，脳 室偏位为改善，脳空はやや搪大し(Fig. 4E)，123日目には CSH は消失し脳溝の拡大を認めた(Fig. $4 \mathrm{~F})$ 。この時点で ンャント主閉放したが，CSHの再発は認められなかった。 <症例10>53才，男性（CSH 自然治癒例）

頭痛扣よび意識障害で発症した右内頸動脈溜破裂症例。 入院後，意識は徐々に患化し，CT お占び脳血管撮影淩た
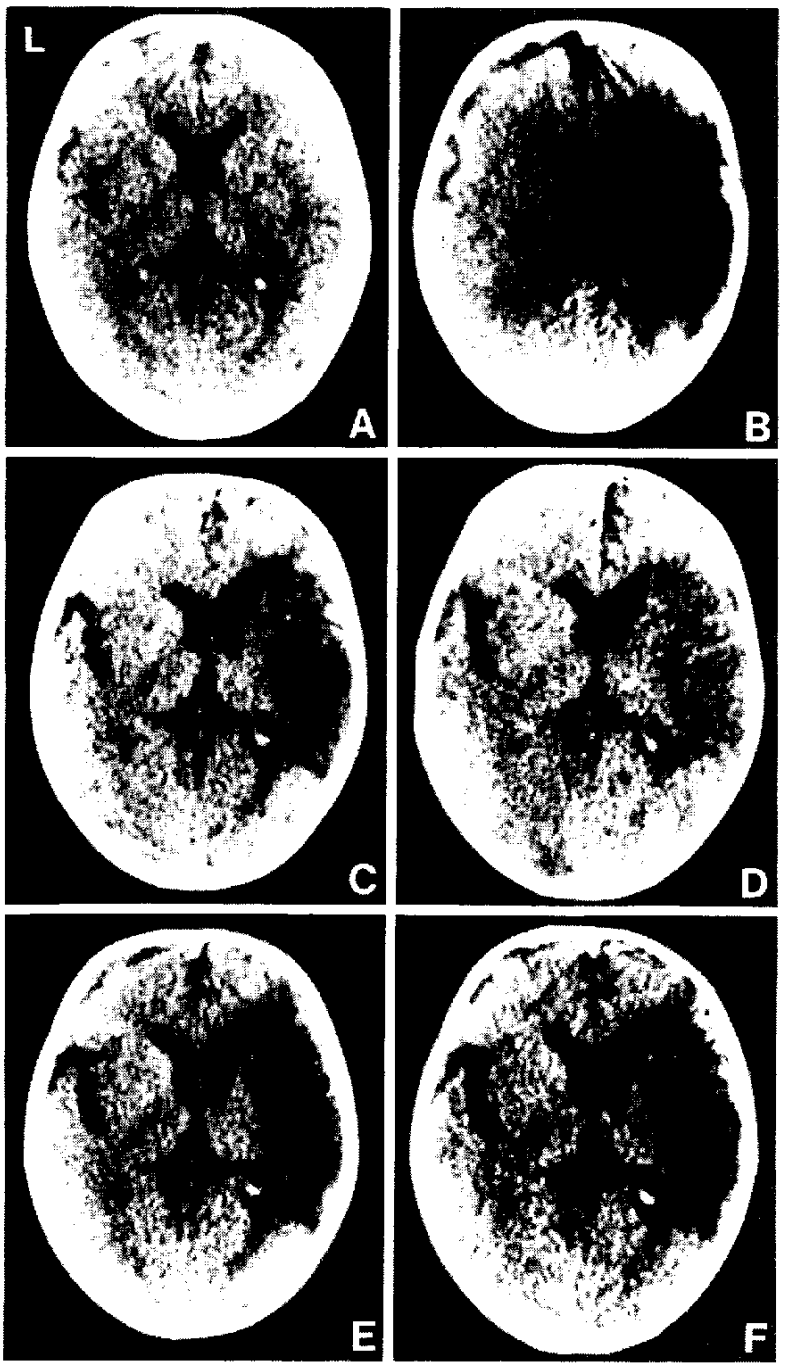

Fig. 5 Case 10. CSH after surgery for aneurysm. A: Preoperative CT scan. B: Left frontal low-density area and low density in the right middle cerebral artery area were noted on day 7 after surgery. C: A left frontal isodense $\mathrm{CSH}$ was shown on day 38 . D: The isodense area bad changed to high density by day 54. E and F: The hematoma decreased gradually wichout treatment (E: day $93, \mathrm{~F}$ : day 122 )

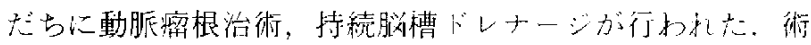

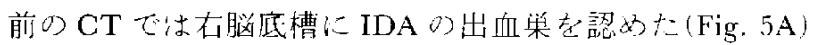

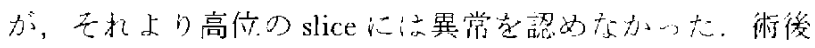

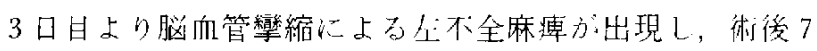
日日のCTでは在中大兴動脈領域が LDAとなり，脳室は

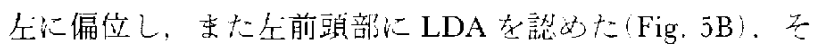
の後, 右大脳半球の LDA心術後10日H境に徐々に減退 した。しかし，左前頭部の硬膜下 LDA 如や增大した状 
Table 1 Summary of 10 cases of chronic subdural hematoma (CSH) after intracranial surgery

\begin{tabular}{|c|c|c|c|c|c|c|c|}
\hline $\begin{array}{l}\text { Case } \\
\text { No. }\end{array}$ & $\begin{array}{l}\text { Agef } \\
\text { Sex }\end{array}$ & $\begin{array}{l}\text { Primary } \\
\text { discase }\end{array}$ & $\begin{array}{l}\text { Secondary } \\
\text { disorder }\end{array}$ & Operation & $\begin{array}{l}\text { Side of } \\
\text { primary } \\
\text { operation }\end{array}$ & $\begin{array}{l}\text { Side of } \\
\text { CSH }\end{array}$ & Treatment \\
\hline 1 & $57 / \mathrm{M}$ & infarction & - & bypass & lt. & lt. & mannitol "surgery \\
\hline 2 & $61 / \mathrm{M}$ & infarction & - & bypass & lt. & lt. & glycerol $\rightarrow$ surgery \\
\hline 3 & $62 / \mathrm{M}$ & infarction & - & bypass & lt. & bil. & no treatment \\
\hline 4 & $61 / \mathrm{M}$ & infarction & - & bypass & rt. & bil. & no treatment \\
\hline 5 & $54 / \mathrm{M}$ & infarction & - & bypass & bil. & lt. & no treatment \\
\hline 6 & $62 / \mathrm{M}$ & $\begin{array}{l}\text { cerebellar } \\
\quad \text { blecding }\end{array}$ & hydrocephalus & shunt & rt. & bil. & $\begin{array}{l}\text { mannitol } \rightarrow \text { surgery, } \\
\text { blocking of shunt system }\end{array}$ \\
\hline 7 & $55 / \mathbf{M}$ & $\begin{array}{l}\text { cerebral } \\
\text { bleeding }\end{array}$ & hydrocephalus & shunt & lt. & lt. & $\begin{array}{l}\text { surgery, } \\
\text { blocking of shunt system }\end{array}$ \\
\hline 8 & $8 / \mathbf{F}$ & hydrocephalus & - & shunt & rt. & bil. & blocking of shunt system \\
\hline 9 & $77 / \mathrm{M}$ & aneurysm & hydrocephalus & shunt & rt. & rt. & blocking of shunt system \\
\hline 10 & $53 / \mathbf{M}$ & aneurysm & - & $\begin{array}{l}\text { neck } \\
\quad \text { clipping }\end{array}$ & rt. & lt. & no treatment \\
\hline
\end{tabular}

Bypass indicates extra-intracranial anastomosis.

態で持続し，術後38月目にはLDAがIDAに変化し CSH となった(Fig. 5C)，CSHは術後54ロ日にHDAとなるも 血腫量は増加せず，93日目で血腫は減少しRLDAとな り，122日日に注消失した(Fig. $5 \mathrm{D} \sim \mathrm{F})$. 経過中，CSH による症状の出現は認めなかった。

\section{3. 症例のまとめ}

非外傷性頭蓋内疾患の術後に発生した CSH 10例の原疾 患, 二次的病態, 手術法, 術後のCSH 発生経過, CSH に詨する治療内容を Table 1 亿示す。年齢㧍よび性别は, 〈症例 8〉除く全例が50才以上の男性で市り，従来報告さ

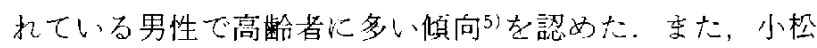
$5^{4 !}$ 放非外傷性頭蓋内疾患の術後に発生: -する $\mathrm{CSH}$ の発生 因子として重視した酒客は，1例のみであった。尿中 estrogen $の$ 問題）为高值例はなかったが，血中 estrogen, 特に去の活性 estrogenである estradiol は5 例に方いて低 值であった，既往歴としては 8 例に高血圧症，2例に精承

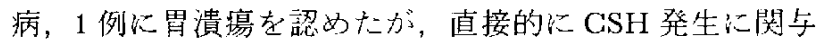
寸る基礎疾患はなかった。術後経過として, CSHに関与 寸る術後の頡部外傷は 1 例乎なく，方ずか１例儿術後数口 間軽いDICを認めたのみであった。

Fig. 6 に10例况おる術後 CT 所見を尗す。術後 CSH の前段階 10 でかる硬膜下 LDA 出現から CT 上 CSHを認 めるまでの期間は，最短 14 日，最長 68 日，平均40.6日であ り，著者がすでに報告9 した外傷後に生じた硬膜下 LDA から CSHになるまでの期間(最短17日，最長64口，平均 40.6日)に類似した。血腄発生部位はすべて前頭部でるり， 開頭部位々血睡発生部位の関倸についてみると，開頭部位 上同側に発生したるのは10例中 5 例，両側発生 4 例，反対
側 1 例であった。さた，〈症例 8〉を除き，血腫は開頭部位 より前力ないしは対側に生じた。CSH 発生による症状は， 手術要した４例ではすへてて認めら机たが，手術を行わ なかった6例では1例にしか認められなかった。

$\mathrm{CSH}$ 発生後の治療経過泣, 10 例中 4 例が血腫の増大山 なく自然治癒し，2 例がンャント遮断のみで治癒，3例は 脳正下降剤の使用により症状は少し改善したが，血腫量は 減少せず手術を要し，1例は意識障害肪出現したためただ らに血腫除去術を行った。な抏，手術老行った4例の手術 所見は，硬膜下に明らかな被膜形成を認永，内容液は暗赤

\begin{tabular}{|c|c|}
\hline \multirow{2}{*}{$\begin{array}{l}\text { Case } \\
\text { No. }\end{array}$} & Postoperative CT findings \\
\hline & $\begin{array}{llllllllll}30 & 40 & 50 & 60 & 70 & 80 & 90 & 100 & 110 & 120\end{array}$ \\
\hline Case 1 & 3437 \\
\hline Case 2 & $45 \quad 67$ \\
\hline Case 3 & $33 \quad 73 \quad 96$ \\
\hline Case 4 & 32 \\
\hline Case 5 & 68 \\
\hline Case 6 & 每篮 $\quad 84 \quad 92$ \\
\hline Case 7 & $4 \quad 18 \quad 36$ \\
\hline Case 8 & -73 \\
\hline Case 9 & 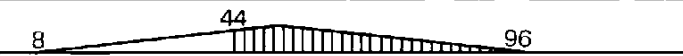 \\
\hline Case 10 & 38 \\
\hline
\end{tabular}

Fig. 6 Postoperative CT findings. open area: Low density (cerebrospinal fluid or air density), hatched area: iso, high, mixed, or relatively low density.

Neurol Med Chir (Tokyo) 27, November 1987 
色，流動性で，典型的な CSHの像を龺していた。さら に，血腫被膜は病理組織学的に楾維芽細胞，管腔の昖大し た毛細血管，リンパ球，好酸球，好中球の浸潤細胞を認 め, 内谷液にも新しい血球上古い変形した血球を認め, FDP $160 \sim 960 \mu \mathrm{g} / \mathrm{d} l$ と高く, こ机らの性状毛外傷性の $\mathrm{CSH}^{11)}$ と汪济同様と考えら机た。

\section{III 考察}

非外傷性頭蓋内疾患の術後経過中心発生 LたCSH の発 生病態を検討寸ることは，(1) $\mathrm{CSH}$ 発生以前の脳の状態お 上び全身状態を把握し5る，(2)発生の契機となる手術内谷 が明らかである，(3)発生後経過を把握しやすいなどの長所 が京り，一般的な外傷性 CSH の発牛病態を検討するより 女信頼性が高いと言兄る。李た，今回の検討から明らかな 上弓に，非外傷性頭蓋内疾患術後に発生した CSH \&外傷 性 CSH と同様に硬膜下 LDA から始まり10!，かっ術後 CSH 発生玉での期間 ${ }^{10)}$, 手術所見 ${ }^{11 !}$, 血腫被膜の病理組 織学的所見 ${ }^{111}$ ，血腫内容液所見 ${ }^{11}$ '外傷性 CSH のそれと さ汪ぞ差異はなく，外傷性 CSH と病態を同じくすると言 えよう。このことから, 非外傷性頭蓋内疾患術後に発生し た CSH の病態を知ることは外傷性 $\mathrm{CSH}$ の病態を知るこ 上につながると考息られ，以下に今回の検討で知り光た CSH の発生因子および増大因子について考察する。

\section{CSH 発生因子}

$\mathrm{CSH}$ の発牛因子として従来きわわて重要とされている 所見 ${ }^{12)}$ は，硬膜下腔の血液を混じた崩液の貯留である。著 者も，外傷性 CSH 発生初期の内容液に血液が混入してい ることを重視した11)。しかし，非外傷性頭蓋內疾患術後に 発生した CSH の検討では，むしろ䯣液と血液の混台が起 こりにくい頭蓋内外血管吻合術, シャント術後に多く発生 したささらにこれらは術野直下ょりもその前方に多く生 した，文献上でもン+ント術後に CSH 発生の多いこ之は 明らかである7。では，頭蓋内外血管吻合術，シャント術 に共通した要因とは何か，それは，硬膜下腔に䯣液などが 容易汇眝留しらることであると思われる。頭蓋内外血管吻 合術が行われる症例は此較的高柃で，脳虚血発作ない儿注 脳梗塞の既往があり，かつ発作後少なくとも2 週以上経過 した症例が多い，つまり，この手術を行り症例は，自験例 でも明らかなよらに，すでに多少なりとも脳萎綟があると 推測される。このよらな状態での手術てよる血管周囲のク モ膜切開は, 容易に硬膜下腔に䯣液の持続的貯留引引起

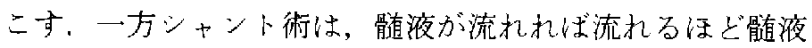
の排除と脳の再構築の間记差が生じ，硬膜下腔やクモ膜下 腔は桩大寸ることになる。この上らな状態では，荒不”が 推測したごとく，傍矢状洞特に前頭部のクモ膜は裂け目を
生じや与く，流出した随液は硬膜下腔に長期間眝留しら る，つまり，頭蓋内外血管吻合術やンャント術後化おいて は倜迹液が硬膜下腔に貯留しやすく，長期間これを残存させ る頭蓋内の条件を有していると言える，また，脳動脈瘤根 治術後にCSH が発生した自験例は，術後約 2 週間持続脳 槽ドレナージを行ったため，脳血管攣縮に上り右大脳半球 が腫脹しているにもかかからら゙ドレナージから䯣液が流出 し，乏のため硬膜下腔に持続的䯣夜貯留が存在し，CSH

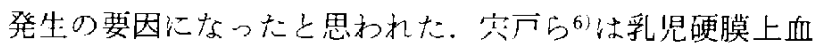
睡除去術後に発生したCSHにおいて発生因子として脳萎 縮の所見を重視しており，末た CSH の発生が高齢者に多 いこともCSH 関与する頭蓋内の条件としての脳の状態 の重要性示唆している13)，以上の知見から，GSH 発生 因子としては，硬膜下腔に血液の混じた䯣液が貯留するこ とよりも，䯣液様眝留液が硬膜下腔に長期間残存しうるこ とのほうがその発生因子としてょり重要であると思わ机 た.

ところで，頭蓋内疾患術後に CT 上硬膜下腔の髄液様貯 留液を認めることはまれではない，今回の娭討では，頭蓋 内外血管吻合術乩よびシャント術を除いた手術後にも術野 直下に髄液様貯留液と言光るLDA 認她。，術後 2 週以 上術野直下の硬膜下腔に多少なり上も LDAを認めた症例 は，脳内血腫除去術後 $12.8 \%$, 脳動脈瘤根治術 $5.6 \%$, 脑 腫堭摘出術 $3.3 \%$ ，また外傷性疾患て出る急性硬膜下血腫 術後には8.7\%であった。しかし，こ扎らの術後経過中に $\mathrm{CSH}$ の発生を認めたものは，脳動脈瘤術後の1例のみで 西った。これらの手術例之頭蓋内外血管吻合術例拈上びシ ナント術例の違いは, 各症例に多少の差遠はあるものの頭 蓋内出血の程度が大きいこと, 脳浮腫など脳腫脹の所見が あること，人工硬膜を用いていることなどが挙げられる。 これらのことから，上記の疾患では(1)血が多く器質化の 反応が強い，(2)脳腫脹により長期間硬膜下詝留液が存在し にくい，(3) CSH の被膜は硬膜から血流を受けており，人 工硬膜ては被膜形成はない，などの理由により. . CSHが発 生しにくいのではないる思われる，以上の考察を前述の CSH 発生因子に付記するならば，CSH の発生には䯣液様 貯留液が硬膜下典に長期閒残存しらる上らな頭蓋内，特に 脳側の条件が重要であり，本大加らるに眝留液に汢䯣液に 血液が多少混じるか，あるいは混じていない状態であるこ 上，さらに生きた硬膜が必要であることが推測された。

\section{CSH 增大因子}

血腫被膜からの出血 ${ }^{14)}$ はまず硬膜下䯣液样眝留液に置さ 換わり，CT上 $\mathrm{CSH}^{(0)}$ となる。しかし，症状を認めるほ どの $\mathrm{CSH}^{9,10}$ 㟍存の硬膜下 LDA 以上の大きさになる必 要がある，その大きくさせる因子が血腫増大因子で每り， 
現在推測されているものに局所線溶の市進 ${ }^{2}$ ， estrogen

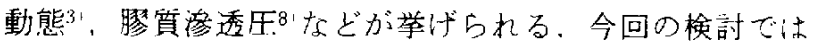
血腫の增大傾向を認めたものは10例中 6 例 $(60 \%)$ で，内訳 は頭蓋内外血管吻合術後 2 例，ンャント術㘼4例であっ た。血腫が增大しなかった 4 例では增大因子は働かなか。 たことになる。この結果から興味深いことは、シャント例 では全例に多少なりとも血腫增大順向を認めたことであ る、つをり、シャント術におけるなんらかの要素が血睡増 大内子上して働いててることを示唆している，著者はこの 因子として，出血点が判らない程度の被膜からの微量の出 血でも、シャント例では脳室から髄液が容易に排除される ことにより血腫が増大しやすい頙蓋内の環境がある，つ市 り䯣液の動態などを含めた脳側の抵抗が弱く compliance が大きいこ上であると考党た。すでに報告したごょく，長 期 CSH 残存例で血腫が再増大しない理由の一つとして, 著者は血腫内膜およびっモ膜の肥厚による敛側の抵抗の増 大を重視した10!。た今回の検討では，2例においてン+ ント遮断をすることだけで CSHは治癒した。これも脳側 の抵抗を示唆する所見であると思われた，以上のことか ら，血腫の増大心は局所的な血腫内膜やクモ膜の肥厚を含 めた脳側の抵抗および complianceが重要な因子でするこ

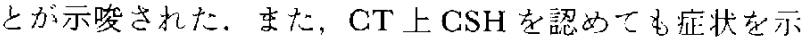
さず自然治重した症例が40\%を占めた。このことから，外

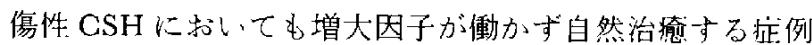
がか店りある上思かれ，治療上 mass signのあるCSH上 ないおのを分けて考完なければならないことが示唆され た.

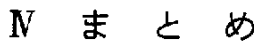

1. 過去 5 年間の外傷性疾患括よび硬膜下水腫を除いた 821 例の非外傷性頭蓋内疾患の術後経過中に，10例(1.2\%)

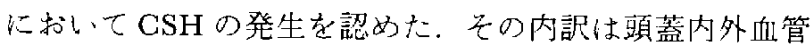
吻合術 5 例，シャント術 4 例，脳動脈瘤根治術1例であ。 た，10例中 4 例は手術により，2 例はシャント遮断のみ, 4 例は自然経過で治瘉した。

2.これら非外傷性頭蓋内疾患術後に発生したCSHの 発生経過，手術所見，血腫被膜所見，内容液心性状は外傷 性 $\mathrm{CSH}$ と注同様であり，同一視できた。このことか ら，今回の検討を通して CSHの発生因子拉よび增大因子 を考察した。その結果，CSHの発生には硬膜下腔に长期 間髄液様貯留液が残存できるよらな頭盖内の状態が必要々
思われた。束た，CSHの増大には，被膜からの微量な出 血に対し谷易に脳が偏位しらるような，髄液の動態を含め た脳側の抵抗が弱く compliance が大きいといら状態が必 要であると思われた。

\section{文献}

1)荒本千里：慢性硬膜下血腫の成因についての新仮説私案. 外科治療 25: 121-123,1971

2) 駒井杜詩夫，伊藤治英，山嶋哲盛，山本信二郎：慢性硬膜 下血腫の成因 一局所線溶元進の観点加ら N Neurol Med Chir (Tokyo) 17: 499-565, 1977

3) 小松伸郎：慢性硬膜卜血腫の原因としての estrogen。脳と 神 27:645-656, 1975

4）小松伸郎，高久 晃，堀重昭：開頭術㣪に発生した慢性 硬膜下血腫の 3 症例。脳神外科 5: 1273-1277, 1977

5) Mckissock W: Subdural hematoma. A review of 389 cases. Lancet 1: $1365-1369,1960$

6）实戸豊史，森 洋：，榊三郎，松岡健三：外伤性急性硬 膜外血腫除去後に続発した両側性慢性硬膜下血腫 $\sigma$ 一乳児例. Neurol Med Chir (Tokyo) 19: 835-841, 1979

7) 来松克美，土田博美，相馬 勤，宮尾邦康：シャン卜手術 倦の硬膜下血腫について。脳神外科 5: 1261-1266, 1977

8）田口芳婎：慢性硬膜下血腫の保存的療法一の期待 一吸収過 程の唂討加与一. 脳上神 34: 999-1005, 1982

9）高橋義男，三上厚一，佐藤宏之，武田 聡，松岡高博，伊 滕和則，上田幹也，大川原修二：慢性硬膜下血腫の CT 的検 討(第 2 報) 一 CT 上推移七症状出現との関連について一一。 Neurol Med Chir (Tokyo) 22: 395-401，1982

10）高橋義男，“上涼一，上男幹也，伊藤和則，位藤宏之，松 岡高博，武田 聡，大川原修二：慢性硬膜下血腫の CT 的桧 討 (第 3 報) 一 CT に上る僈性硬膜下血腫の病期分類一. Neurol Med Chir (Tokyo) 24: 607 614, 1984

11) 高橋義男, 三上淳一, 上田幹也, 伊滕和則, 佐藤宏之, 松 岡高博, 武田 聡，大川原修二，大宮信行：発生か坫消褪玉 での血腫被膜所見已内容液所見から支大慢性硬膜下血腫の成 因の臨床的研究. Neurol Med Chir (Tokyo) 25: 998-1009, 1985

12) 渡辺学, 島田裕旦，石井昌三：実験的慢性硬膜下血腫の 作成について。，神経進步 14:387-396, 1970

13)山本信二郎：慢性硬膜下血腫. Neurol Med Chir (Tokyo) 19: $401-409,1979$

14）山本信:郎，伊藤治英，水腰英隆，吉田早苗：慢性硬膜下 血腫に衫计万被膜加らの出血の意義. 脳神外科 2：239-242, 1974

〔別刷請求先: $\overline{\mathbf{T}} 047-02$ 北海道小樽市銭啲1-10-1，北海道立小 垐総合保健センター脳神経外科, 高橋義男] 